\title{
Joint patenting amongst companies - exploring the effects of inter-firm R\&D partnering and experience
}

Citation for published version (APA):

Hagedoorn, J., van Kranenburg, H. L., \& Osborn, R. N. (2003). Joint patenting amongst companies exploring the effects of inter-firm R\&D partnering and experience. Managerial and Decision Economics, 24, 71-84. https://doi.org/10.1002/mde.1078

Document status and date:

Published: 01/01/2003

DOI:

10.1002/mde.1078

Document Version:

Publisher's PDF, also known as Version of record

\section{Please check the document version of this publication:}

- A submitted manuscript is the version of the article upon submission and before peer-review. There can be important differences between the submitted version and the official published version of record.

People interested in the research are advised to contact the author for the final version of the publication, or visit the DOI to the publisher's website.

- The final author version and the galley proof are versions of the publication after peer review.

- The final published version features the final layout of the paper including the volume, issue and page numbers.

Link to publication

\footnotetext{
General rights rights.

- You may freely distribute the URL identifying the publication in the public portal. please follow below link for the End User Agreement:

www.umlib.nl/taverne-license

Take down policy

If you believe that this document breaches copyright please contact us at:

repository@maastrichtuniversity.nl

providing details and we will investigate your claim.
}

Copyright and moral rights for the publications made accessible in the public portal are retained by the authors and/or other copyright owners and it is a condition of accessing publications that users recognise and abide by the legal requirements associated with these

- Users may download and print one copy of any publication from the public portal for the purpose of private study or research.

- You may not further distribute the material or use it for any profit-making activity or commercial gain

If the publication is distributed under the terms of Article $25 \mathrm{fa}$ of the Dutch Copyright Act, indicated by the "Taverne" license above, 


\title{
Joint Patenting Amongst Companies-Exploring the Effects of Inter-Firm R\&D Partnering and Experience
}

\author{
John Hagedoorn ${ }^{\mathrm{a}, *}$, Hans van Kranenburg ${ }^{\mathrm{a}, \dagger}$ and Richard N. Osborn ${ }^{\mathrm{b},}$ \\ ${ }^{a}$ MERIT, Faculty of Economics and Business Administration, University of Maastricht, \\ Maastricht, The Netherlands \\ ${ }^{\mathrm{b}}$ Department of Management, School of Business Administration, Wayne State University, Detroit, MI, USA
}

\begin{abstract}
R\&D alliances and previous experience with the sharing of intellectual property rights are expected to have significant effects on joint patenting by alliance partners. Although so far unresearched, this is both an intuitively and theoretically appealing subject because joint patenting could relate to the possible outcome of an important group of alliances. However, the main explanation for differences in joint patenting of $R \& D$ partners is found in their experience with the joint patenting process itself. Copyright $(\mathbb{C} 2003$ John Wiley \& Sons, Ltd.
\end{abstract}

\section{INTRODUCTION}

The purpose of this paper is to explore the relationship between inter-firm R\&D partnerships and joint patenting for companies that are engaged in formal R\&D collaboration. Exploratory studies such as the current paper can be important contributions to the literature when they test the boundaries of existing theoretical explanations and help to move research into uncharted areas. This paper tests four hypotheses related to prior literature concerning experience of companies with inter-firm partnering and it extends the growing literature on cooperative $\mathrm{R} \& \mathrm{D}$ with the evaluation of the effect of formal R\&D cooperation on joint patenting.

A starting point for this study can be found in the large body of literature that points at the growing importance of a wide variety of inter-firm

\footnotetext{
*Correspondence to: John Hagedoorn, MERIT, Faculty of Economics and Business Administration, University of Maastricht, PO Box 616, 6200 MD Maastricht, The Netherlands.

E-mail: j.hagedoorn@mw.unimaas.nl

†h.vankranenburg@mw.unimaas.nl

†aa4322@wayne.edu
}

Copyright (C) 2003 John Wiley \& Sons, Ltd. partnerships, a growth that has manifested itself in particular since the 1980s. That same literature also suggests that joint $R \& D$ is one of the most popular reasons for forming alliances in many socalled high-tech industries and emerging technical areas (see Hagedoorn, 1993; Mowery, 1988; Mytelka, 1991). Commensurate with the growth of cooperative $\mathrm{R} \& \mathrm{D}$ we also observe an increase in the number of jointly owned patents (Hicks and Narin, 2000). An initial screening of US patents suggests that by the end of the 1990 s about $8 \%$ of US patents in a number of high-tech sectors was jointly owned by two or more companies. This percentage seems to be the result of a gradual, unrecognized increase in the willingness of firms to jointly share their property rights in technical discoveries. The choice to share property rights seems to reflect an important milestone in sustained inter-firm cooperation since the subsequent development and benefits of the invention would also likely be shared. That is, filing a joint patent may be seen as an important landmark signifying the successful completion of inter-firm cooperative R\&D and a milestone suggesting future collaboration as the discovery is moved toward commercial success. 
The premise to be examined is as follows: One of the more important intermediate outcomes of $\mathrm{R} \& \mathrm{D}$ is a patent. These patents provide the holder with valuable intellectual property rights that can be used to develop a unique competitive advantage. Given the importance of joint R\&D in interfirm partnering, joint patenting could be a valuable outcome of joint R\&D once companies have built up some experience in working with others and/or with a specific partner.

In the following we will first describe both joint patenting and $R \& D$ partnering in detail to provide the background for the hypotheses. This is followed by the discussion of four hypotheses that stipulate the expected relationship between $R \& D$ partnerships and joint patenting, as well as the possible effect of previous joint patenting activities on joint patenting at a later stage. In order to test our hypotheses we will construct a relatively large data set that merges a number of databases on R\&D partnerships, joint patenting, and a variety of company indicators. Given the specifics of our data and our research questions, we will discuss and use four different statistical analyses: a standard ordinary least square regression model, a log-linear model, a Poisson model and a negative binomial model. This methodological discussion is followed by sections that present and discuss the results of our exploratory study. Finally, we briefly discuss some of the major conclusions from this research.

\section{CONCEPTUAL FRAMEWORK AND HYPOTHESES}

We believe it is of particular importance for an exploratory study to first discuss its major subjects, here joint patenting and R\&D partnering, before presenting elements of theory development, hypotheses and operational measures.

Joint patenting refers to the condition where two or more patent-holders (e.g. companies) hold property rights to a registered discovery. In that situation two or more co-assignees are understood to have jointly filed a patent with a patent office. These joint patents are quite different from other patent agreements, such as cross-licenses and pooled patents. Cross-licensing usually occurs when patents of different companies 'block' each other because each patent infringes one or more patents of another company. In that case, a crosslicensing agreement, based on patent-exchanges or 'swaps', gives the right to use these patents by parties that are subject to the exchange agreement. For pooled patents, companies decide to pull together patents, that do not necessarily infringe each other's patents, in order to improve products using patents of different patent-owners. Both, pooled patents and cross-licenses, are based on separately filed individual patents. In both instances the companies decide to 'share' the property rights of specific patents to avoid blocking the patent rights of inventions that were made by individual companies.

A joint patent, however, is a specific form of a standard patent where the 'owners' or assignees are two or more separate companies that share the property rights of a particular jointly filed patent. Joint patenting expresses a mutual relational trust between separate companies that acknowledge their shared intellectual property rights and the joint ownership of an invention, an artifact or a new technology that is registered as a patent.

The diversity in forms of formal cooperation and their different organizational settings does also demand that one attempts to define as exact as possible which forms of inter-firm cooperation will be studied. In the following we will refer to $R \& D$ alliances and $R \& D$ partnerships as a set of different forms of collaboration where joint R\&D is at least part of the agreement between distinct companies. (We will use concepts such as alliances and partnerships as synonyms that indicate a similar degree of collaboration between companies.) There are two major sub-categories of these formal R\&D alliances: R\&D joint ventures and joint $R \& D$ agreements. An $R \& D$ joint venture refers to the combination of the economic interest of at least two distinct companies in a jointly owned organization. The jointly owned firm is expected to have a number of standard company objectives (including R\&D as a major objective) and operates as a separate business unit. Profits and losses of the joint venture are usually shared according to equity investment of the parentcompanies. Although R\&D joint ventures were the dominant form of R\&D partnering during the 1970s (about $70 \%$ of R\&D alliances), the dominant form of R\&D partnering in the 1990s are the joint R\&D agreements (about 80\%) (Hagedoorn and Narula, 1996). These joint R\&D agreements refer to incomplete contracts (Williamson, 1996) 
between companies that establish and regulate the joint undertaking of temporary $R \& D$ projects with shared resources. $R \& D$ pacts, joint development agreements and long-term research contracts are examples of these joint R\&D agreements.

So far numerous studies suggest a dramatic increase in both formal and informal $\mathrm{R} \& \mathrm{D}$ cooperation among firms (see e.g. Bouty, 2000; Hagedoorn, 1993; Hagedoorn and Narula, 1996; Osborn and Baughn, 1990; Von Hippel, 1988). Based on the well established relationship between R\&D and patents (see Griliches, 1998) we can also expect a relationship between the joint $R \& D$ efforts of firms and joint patenting. Here we are concerned with sustained formal cooperative relationships between firms rather than the informal cooperation that naturally emerges as scientists and engineers from different firms consult one another to solve their individual technical problems (e.g. Bouty, 2000).

Prior work on formal partnerships typically has also sought to link antecedents to alliance outcomes, either the overall success of the partnership (e.g. Geringer, 1991; Glaister and Buckley, 1999) or directly to the bottom line of one or more sponsors (Balakrishnan and Koza, 1993; Hagedoorn and Schakenraad, 1994). Others have suggested that most alliances are intended for specific purposes, such as R\&D, and that a specific partnership between firms may well be embedded in a larger set of relationships (Gulati, 1995a, b; Heide and Miner, 1992; Levinthal and Fichman, 1988; Saxton, 1997). This embeddedness could be important for our understanding since the specifically measured outcomes from alliances intended to conduct joint $\mathrm{R} \& \mathrm{D}$ could be viewed not as isolated outcomes but as part of a pattern of sustaining relationships among firms that encourages trust among these companies. Specifically this prior work yields a set of expected relationships among experience and setting factors when predicting possible alliance outcomes such as joint patenting.

\section{Experience of Companies with R\&D Partnering Affecting Joint Patenting}

A substantial part of the literature stresses that the success of a company in inter-firm partnering is to a large extent based on its experience with alliances (e.g. Barkema et al., 1997; Kale and Singh, 1999; Anand and Khanna, 2000). The more experienced a company is in establishing formal alliances, the more opportunities are created to further develop existing linkages (Park and Ungson, 1997) and to enter into future partnerships (Dyer and Singh, 1998; Gulati, 1995a; Powell et al., 1997; Oster, 1992). Beyond learning who to form an alliance with, how it should be administered and when an alliance should be formed, firms with more alliances may increase their reputation and attract more desirable partners (Powell et al., 1997).

Based on the increased experience and the growth of relevant managerial capabilities that companies develop over time, they can also decide that they can afford to take some risk in collaborating with other companies. This calculated risk based on the experience with a number of companies implies that experienced companies are more likely to extend their R\&D partnerships with others into long-term in-depth $\mathrm{R} \& \mathrm{D}$ collaboration. One particular dimension of such an extended form of R\&D collaboration could be the joint ownership of the results of these formal collaborative efforts. In that case, companies can decide not to individually allocate their joint inventive output into different patents but to pool the results of some of these alliances by means of shared intellectual property rights.

Prior working experience with R\&D partnerships would lead companies to extend their joint patenting with others because their experience builds up capabilities in managing these relationships. Thus, there should be a positive relationship between the general experience with R\&D partnering and joint patenting:

\section{Hypothesis 1:}

There is a positive relationship between the general experience of companies with setting up $R \& D$ partnerships and their involvement in joint patenting.

\section{History of R\&D Collaboration Between Partners Affecting Joint Patenting}

Research by Gulati (1995a) stresses the positive effect that past partnering experience of pairs of companies has on the probability of their future relationships. Earlier work by Heide and Miner (1992) had already shown that the history of prior relations between companies, if understood in terms of the frequency of their contacts, can have 
a positive effect on the nature of their future relationship. Specifically, the contribution by Heide and Miner (1992) suggests that companies are willing to add new dimensions to their collaboration if previous cooperation has generated positive results. Levinthal and Fichman (1988) also found somewhat similar results with regard to the effect of prior relations on new relations between the same partners. Their research reveals that once companies have gone through a difficult, initial period of collaboration, in which they learn how to operate alliances, they gradually initiate more complex relationships with the same companies. These contributions are consistent with Kogut's (1989) expectation that prior experience of formal collaboration with multiple contacts between partners encourages reciprocity and mutual concessions. This should also yield more enduring linkages across the different stages of $R \& D$.

Although there are differences, these studies imply that shared experience encourages companies to gradually add new dimensions to their alliances. We submit that shared intellectual property rights through joint patenting could reflect such an extra dimension of collaboration. For instance, joint patenting would suggest that companies have taken another step beyond ordinary collaboration in one or more research projects as they choose to unify their property rights through the ownership of inventions born from their collaboration.

Related to this effect of the previous contacts on the extended relationship between companies is the issue of trust. Relational trust is based on the experience of interaction between two or more separate companies (Ring and van de Ven, 1992). Relational trust is developed further by means of multiple contacts between the same companies. Gulati (1995b), Nooteboom et al. (1997) and Saxton (1997) suggest that prior relationships create relational trust between companies as they enrich their collaboration. Gradually this relational or interorganizational trust is expected to become institutionalized trust that influences the content of the exchange between partners (Zaheer et al., 1998). We submit that in the context of formal, joint R\&D projects this institutionalized trust can lead to shared intellectual property rights for the results of joint R\&D by separate companies. Based on this interpretation of the literature, both multiple contacts between companies and their increased institutionalized trust will have a positive effect on the joint patenting between these companies. Hence:

\section{Hypothesis 2:}

There is a positive relationship between the degree of R\&D partnering between companies and their joint patenting.

\section{Experience with Joint Patenting Affecting Joint Patenting}

In the previous sections we emphasized the possible effect of institutional trust through formal R\&D alliances and experience with these partnerships on joint patenting. However, it has to be stressed that the relationship between inter-firm R\&D partnering and joint patenting is not necessarily of a direct nature. Joint patenting is just one of the possible results of R\&D alliances. As with so many other aspects of company behaviour, it might also be the experience of companies with a particular activity, in this case joint patenting itself, that has a positive effect on the propensity of companies to engage in joint patenting. This does not necessarily imply a certain path dependency but it does reflect the effect of experience and learning how to deal with other companies in the process of joint patent application. As companies have engaged in an increasing number of joint patenting agreements they are expected to have learned how to arrange such patent applications. Assuming that companies are rational, we can expect that already a small number of such joint patenting arrangements will indicate to the companies whether this is an instrument of intellectual property rights that they intend to apply frequently or not. Hence:

\section{Hypothesis 3:}

There is a positive relationship between the general experience of companies with joint patenting and their joint patenting at a later stage.

The linkage between experience with joint patenting and joint patenting at a later stage may reflect both the experience between specific partners and their decision to use joint patenting in the past. That is, relational trust represented in prior joint patenting would yield subsequent joint patenting. This concerns the trust coupled with the expertise of jointly filing derived from previous 
joint patenting agreements. In that case, prior specific experience of pairs of companies with joint patenting, their interaction and the multiple contacts between two particular companies and their R\&D personnel, is expected to have a positive effect on the degree to which these companies are willing to continue to jointly own intellectual property rights. Therefore,

\section{Hypothesis 4:}

There is a positive relationship between the degree of previous joint patenting of specific pairs of companies and the joint patenting of the same partners at a later stage.

\section{POPULATION, DATA AND VARIABLES}

In order to test the hypotheses, we had to first construct and later merge two data sets: one on jointly owned patents and one data set on $R \& D$ partnerships. For the data on jointly owned patents we acquired a specific data set from CHI Research Inc. on US patents (co-assigned patents) of companies for the period 1989-1998 in patent classes that coincide with the industry-classifications in the CATI database on alliances (see below). The period 1989-1998 was chosen because the end of the 1980s mark the start of a period of gradual growth in the number of co-assigned patents (see also Hicks and Narin, 2000). The general population of jointly owned patents that forms the starting point for our research comprises a total of 9585 patents, with 20569 assignees and 13052 pairs of assignees or pairs of companies. From this data set we selected the joint patents owned by companies from North America (USA and Canada) and Europe (EU and EFTA). We excluded joint patents with companies from other countries because in many countries, Japan and Korea in particular, it is difficult to detect whether two 'firms' mentioned as coassignees of patents are actually a part of the same complex 'company' such as a Keiretsu or a Chaebol. For North American and European companies we could check whether co-assignees in these patents are indeed two separate companies through Disclosure.

As part of our study focuses on the role of $R \& D$ partnerships we used the MERIT-CATI data set for information on R\&D alliances of North American and European companies (see below).
After matching the two data sets we found that 1122 pairs of companies in the CATI data set were also present in the data set with 13052 pairs of companies with jointly owned patents. The next step was to find the specific pairs of companies that formed an R\&D partnership before the year their latest joint patent was granted. This reduced the number to 226 jointly owned patents with 78 pairs of North American and European companies that are co-assigned to these patents. In other words, these 78 pairs of companies can have multiple jointly owned patents after their latest R\&D partnerships and they can have multiple jointly owned patents before their latest partnership. Also, the companies in these 78 pairs can have joint patents with other companies (1122 minus 226 joint patents) and R\&D partnerships with other companies (958 minus 254 R\&D partnerships that these 78 pairs share).

Consequently, the unit of analysis in our research is the pairs of companies that have at least one jointly owned patent following an $R \& D$ alliance between a pair of companies.

\section{Variables}

The dependent variable in our research is the number of jointly owned patents by pairs of companies after their last partnership was formed during the period 1989-1998.

The general experience with $R \& D$ partnerships reflects the average number of all previous partnerships of both companies in a pair, previous to their latest partnership during the period 1989-1996.

The specific experience with $R \& D$ partnerships reflects the number of partnerships between the companies in a pair, previous to their latest partnership during the period 1989-1996.

The general experience with joint patenting considers the average number of the previous total joint patenting of both companies in the period 1989-1996, prior to the joint patents taken for the dependent variable.

The specific experience with joint patenting is the number of co-assigned patents of the two companies in a pair in the period 1989-1996, prior to the joint patents taken for the dependent variable.

\section{Control Variables}

For this study we apply a number of variables that could influence both $R \& D$ partnering of 
companies and joint patenting. Previous studies indicate that the size of companies affects the degree to which companies enter into alliances and secure their inventive output through patents. There is a well-established body of literature that stresses that alliance formation increases with the size of companies, see Berg et al. (1982), Duysters and Hagedoorn (1995), Ghemawat et al. (1986), Hagedoorn (1995), Mowery (1988) and Mytelka (1991). The study of the effect of size of companies on their patenting goes back to the classical Schumpeterian argument which argues that R\&D and patent activity of companies increases with firm size (Cohen and Levin,1989; Scherer,1965, 1984; Mansfield, 1986; Mueller, 1986). We assume that this size-effect is not only relevant for patents in general but also for jointly owned patents. Size is the log of the average size (revenues in 1995) of both companies in the pairs.

The relation between $R \& D$ intensity of companies and patenting is well established and has been studied extensively. Studies by Bound et al. (1984), Hausman et al. (1984), Kamien and Schwartz (1982) and Scherer (1984) indicate a direct relation between R\&D effort and patenting output, although the relation may not be linear. We assume a similar effect for the R\&D of companies on jointly owned patents. With growing $R \& D$ expenses, these $R \& D$ intensive companies are also interesting partners for R\&D partnerships. $R \& D$ intensity is measured as the average $R \& D$ expenses in each pair as a percentage of total revenues in 1995.

We also control for the number of patents that companies have applied for during the period 1989-1996. First, similar to the effect of R\&D intensity, we expect an effect of the number of patents, that a company has, on its attractiveness as an R\&D partner. Second, the experience that companies have with patenting increases their familiarity with the patent application process which is expected to positively influence their propensity to enter into joint patenting agreements with other companies. We took the log of the average number of US patents of both companies in the pairs during the period 1989-1996 as an indicator for this variable.

High-tech sectors are, almost by definition, sectors with a high-patenting intensity and a disproportionate share in industry-wide patenting (Griliches, 1998; OECD, 1992). Also, high-tech sectors have a disproportionate share of alliances in general and R\&D alliances in particular (Hagedoorn and Narula, 1996; Mytelka, 1991; Osborn and Baughn, 1990; Osborn and Hagedoorn, 1997; Oster, 1992). Therefore, we control for the role of high-tech sectors and the large share of $R \& D$ partnerships in these sectors, which are expected to affect the degree of joint patenting by companies. The degree of high-tech R\&D partnering is the average percentage of high-tech partnerships in $\mathrm{R} \& \mathrm{D}$ partnerships of both companies during the period 1989-1996. According to the OECD (1992) and subsequent OECD publications, high-tech sectors are defense, aircraft and space, information technology sectors, pharmaceuticals and heavy electrical equipment, all with an average sector R\&D intensity of over $10 \%$. Nearly, $30 \%$ of the pairs of companies in this sample are active in these high-tech sectors.

Differences between international and domestic partners might affect the joint patenting behaviour of companies. Conventional understanding of alliances suggests that, given the lack of information on possible international partners, the costs involved with obtaining this information, the cost of control in long-distance arrangements, and the difficulty with developing trust with international partners, companies prefer domestic alliances. This is expected to be even more so when R\&D becomes a more central element in cooperation (Buckley and Casson, 1988; Contractor and Lorange, 1988; Hagedoorn and Schakenraad, 1994). Then, R\&D efforts critical to the future innovative success of companies have to be guarded against potential opportunism in alliances. This suggests that also a disproportionate share of joint patenting is found in domestic R\&D partnerships. The domestic nature of R\&D partnerships is the average percentage of all the domestic R\&D partnerships of both companies in their total number of R\&D partnerships during the period 1989-1996. Domestic partnerships are registered according to the country of origin of the headquarters of companies

Different organizational forms of partnering, such as joint $R \& D$ agreements and joint ventures, play an important role in the management and organization literature on inter-firm cooperation (Dyer and Singh, 1998; Gulati, 1995a; Osborn and Baughn, 1990; Osborn and Hagedoorn, 1997; Oster, 1992). We can expect that these forms also have a different impact on joint patenting. From a traditional transaction cost theory inspired 
perspective one could expect that a joint venture is a quasi firm-like setting where companies collaborate in a separate organizational entity where relational trust between parent-companies develops gradually as the joint venture is engaging in a growing number of activities (Hagedoorn, 1993). The R\&D of the jointly owned company is, given the multitude of tasks of a joint venture, embedded in many other activities. Relational trust between partners is a central element in the long-term perspective of a joint venture and the joint patenting of the parent companies seems a logical consequence of the trust-building that emerges within a joint venture. In contrast to this, contractual $\mathrm{R} \& \mathrm{D}$ agreements are by definition incomplete contracts and, given the nature of incomplete contracts, one could submit that relational trust cannot be developed up to the level where companies would aim at joint patenting.

Collaboration in contractual $\mathrm{R} \& \mathrm{D}$ agreements is expected to fall short in joint patenting as partners will make sure they can, given the uncertainty surrounding incomplete contracts, separate the intellectual property rights related to inventions from their partner(s). Companies will perform joint R\&D through their alliance but the translation of this R\&D into intellectual property rights will take place at each of the individual parent-companies. Hence, joint ventures, that provide better legal protection and an adequate organizational setting, are expected to lead to more joint patenting than joint $\mathrm{R} \& \mathrm{D}$ agreements.

However, we can also follow another line of argument. As suggested by Gulati (1995b) contractual agreements are based on knowledge-based trust where equity is no longer necessary as a safeguard in the alliance. Relational trust between partners emerges through multiple contacts and as this relational trust develops, there is less need for safeguards through equity sharing. Then, relational trust can just as well develop in contractual agreements as in joint ventures.

Given the importance attached to organizational features of inter-firm partnering, we introduce two variables to control for the effect that different forms of inter-firm $R \& D$ partnering might have on joint patenting. The first of these control variables is the share of joint ventures in the total number of $R \& D$ partnerships of both partners in pairs of companies during the period 1989-1996. The other control variable, share of specific joint ventures, refers to the share of joint ventures in the $R \& D$ partnerships made among the pairs of companies during the period 1989-1996.

\section{Data Sources}

Data on joint R\&D partnering were obtained from the MERIT-CATI database on technology alliances. This data bank contains information on thousands of technology-related inter-firm alliances, collected through various sources: specialized journals which report on business events and newspaper and journal articles. The data bank contains information on each agreement and some information on companies participating in these agreements. Alliances are defined as common interests between independent (industrial) partners which are not connected through (majority) ownership. In the CATI database only those inter-firm agreements are being collected that contain some arrangements for transferring technology or joint research. Joint research pacts are clear-cut examples. Information is also collected on joint ventures in which new technology is received from at least one of the partners, or joint ventures having some R\&D programme. Mere production or marketing joint ventures are excluded. In other words, this material is primarily related to $R \& D$ collaboration and technology cooperation, i.e. those agreements for which a combined innovative activity or an exchange of technology is at least part of the agreement. Additional information on this databank can be found in Hagedoorn (1993).

The database on co-assigned patents was constructed by CHI Research Inc. from a subset of patents issued by the US Patent and Trademark Office (USPTO). The selected patents fit the following criteria:

1. They are so-called Type 1 (utility) patents granted in the years 1989-1998.

2. Patents are co-assigned to at least two companies that do not share a common parent company (organizations other than companies are excluded).

3. Patent classifications for these patents coincided with the industry classification of the MERITCATI database.

Data on co-assigned patents are available at the level of individual companies, patent classes and SIC-related product groups, and countries. 
Additional detailed information on the database and the selection of patents is available from the authors.

Data on the number of patents for one of the control variables was obtained from the US Patent and Trademark Office. Although this US data could imply a bias in favour of US companies and against non-US firms, the group of non-US companies in this sample represents a group of firms that are known to patent world wide. Furthermore, the literature suggests several other reasons to take US patents as an indicator. Frequently mentioned are the importance of the US market, the genuine patent protection offered by US authorities, and the level of technological sophistication of the US market which makes it almost compulsory for non-US companies to file patents in the USA. See Patel and Pavitt (1991) for a discussion on the use of US patent data.

For information on firm size and R\&D expenditures we used the well-known databanks of Compustat and Worldscope. In order to aggregate patents of subsidiaries to the corporate level we used information from Disclosure and the Tech Line database to identify parent companies and their subsidiaries.

\section{METHODS AND SPECIFICATION OF ANALYSIS}

Because the observations of jointly owned patents are non-negative integer-valued random count data, the classical linear regression models based on the principle of ordinary least square could provide an incomplete description of the jointly owned patent data. The reasons for the deviation of count data from the classical linear regression assumptions are twofold. The shape of the observation set does not correspond to a linear model and the disturbances of a linear model, with a discrete dependent variable with strictly nonnegative values, cannot be normally distributed (Gourieroux et al., 1984b). To provide a methodological improvement over the classical linear (OLS) regression models, models for analysing jointly owned patents require a framework based on a discrete probability distribution.

The statistical benchmark model for the analysis of cross-section discrete data is the Poisson model (Hausman et al., 1984; Cameron and Trivedi,
1986). With the distribution of the number of jointly owned patents specified as Poisson, we are able to estimate the probability of the number of jointly owned patents between pairs of companies after they established their last partnership.

However, the Poisson regression model has an important restrictive assumption. It is based on the assumption that the conditional mean and the variance of the dependent variable, given the explanatory variables, are equal. Many empirical distributions of count data, though, have a variance exceeding the mean and are thus overdispersed relative to the Poisson rate. The negative binomial regression model provides a mechanism for incorporating overdispersion in the count model (Gourieroux et al., 1984a, b; Hausman et al., 1984; Cameron and Trivedi, 1986). This regression model embeds the Poisson distribution in a more general distribution that allows the variance of the process to differ from the mean.

A natural basis for testing the adequacy of the Poisson regression model is the variance-mean equality, conditional on explanatory variables. Classical standard methods to test the failure of restrictions are the likelihood ratio test and the Wald test. Cameron and Trivedi (1990) have proposed a number of regression-based tests for overdispersion in the Poisson regression model. They found that the optimal test is the one that tests the assumption of variance-mean equality, $\operatorname{var}\left(y_{i}\right)=\mu_{i}$, as null hypothesis, against the alternative hypothesis $\mathrm{H}_{1}: \operatorname{var}\left(y_{i}\right)=\mu_{i}+\alpha g\left(\mu_{i}\right)$, where $g\left(\mu_{i}\right)=\mu_{i}$ or $g\left(\mu_{i}\right)=\mu_{i}^{2}$, where $y_{i}$ is dependent variable. If $\alpha=0$, then the evidence shows the existence of mean-variance equality in the count data set.

For comparison purposes, four versions of the model specifications are estimated below: a linear regression model, a log-linear model, a Poisson model, and a negative binomial model. The classical linear model group is estimated by OLS and the discrete probability distribution group by the maximum likelihood method. We compare the OLS estimates with those of the specific econometric count data models to show the extent to which the effects of the explanatory variables on the number of jointly owned patents is robust and whether the effect of changes in specifications of the model makes a difference. The second investigation focuses on the improvements that are made by using the statistical procedure that 
recognizes that joint patenting is measured as discrete non-negative integer data.

Observations regarding the general and specific experience with R\&D partnerships and the general and specific experience with joint patenting are conversed in log variables. However, this transformation has one limitation, i.e. the logarithm transformation of zero values is not possible. Following the work of Hausman et al. (1984), we set these specific transformed values to zero and a dummy variable is used to correct for this solution. The other explanatory variables are also measured in logarithms, in percentages, or as dummies. These procedures leave the relationships between the jointly owned patents and each of the explanatory variables in percentage terms, either by definition of the variable itself as a percentage, or by expression in logs.

\section{RESULTS}

Table 1 provides descriptive statistics and correlation coefficients for all variables. Table 2 displays estimation results of the various statistical models for jointly owned patents of pairs of companies. In models 1-4 we estimated the effects of the experience variables and control variables on the number of jointly owned patents of pairs of companies after their last R\&D partnership. In models 5-8, we added the effects of the control variables for average size of the pair of companies and their average R\&D intensity. In order to choose between the Poisson and negative binomial model, we tested the null hypothesis that the underlying model is Poisson with the meanvariance equality, against the alternative hypotheses that the model is a negative binomial with variance $=\mu_{i}+\alpha \mu_{i} \quad$ or $\quad$ variance $=\mu_{i}+\alpha \mu_{i}^{2} \quad$ with $\mu_{i}=E\left[y_{i} \mid X_{i}, \beta\right]$, corresponding with negative binomial models I and II, respectively (Cameron and Trivedi, 1986).

Table 3 shows the results of the regression-based tests for overdispersion of Poisson models. The tests show evidence of overdispersion in the data, since $\hat{\alpha}$ is significantly different from zero in the second regression-based test. We estimated, therefore, the negative binomial model II which allows the variance process to differ from the mean according to the results of the second regressionbased test. The corresponding likelihood-ratio test statistics for models 3, 4 and 7, 8, are 8.578585 and 8.055587 , respectively. These statistics are highly significant. However, the estimation of the additional overdispersion parameter $\alpha$ in both models 4 and 8 weakens the rejection of the Poisson model. However, we cannot reject the Poisson distribution in favour of the negative binomial model II as their estimates are quite similar in size and magnitude. Also, the standard errors under the Poisson are substantially smaller. This reflects the consequence of imposing the mean-variance equality restriction of the Poisson distribution. These findings are consistent with those of Hausman et al. (1984) and Cameron and Trivedi (1986).

In hypothesis 1 we argued that the general experience with $R \& D$ alliances of companies will stimulate their number of jointly owned patents. However, in all models the general experience with R\&D partnerships is insignificantly associated with the number of jointly owned patents. We also hypothesized that the specific experience of pairs of companies with $\mathrm{R} \& \mathrm{D}$ partnering through partnerships with each other, will contribute positively to their number of jointly owned patents (hypothesis 2). The estimates of this specific term in all models are insignificantly different from zero. These results suggest that the experience of companies with $\mathrm{R} \& \mathrm{D}$ alliances, either in a general or in a pair specific context, does not have predicting power with regard to pairs of companies with these characteristics having more jointly owned patents. Thus, hypotheses 1 and 2 are not supported.

Table 2 also shows the results for the analyses testing hypotheses 3 and 4 . As predicted, the two experience terms with jointly owned patents, the general experience with jointly owned patents and the specific experience with joint patenting of particular pairs of companies, are positively associated with the number of jointly owned patents for a pair of two companies at a later date. The general experience with joint patenting is significant in all our models, while the specific experience is only significant in the classical linear model (models 1 and 5) and in the Poisson model (models 3 and 7). The estimation results from the log model (models 2 and 6) and the negative binomial model II (models 4 and 8) moderate the relationship between the specific experience with joint patenting and the number of jointly owned patents. Most of the joint patenting experience variables in the count data regression tell the same 


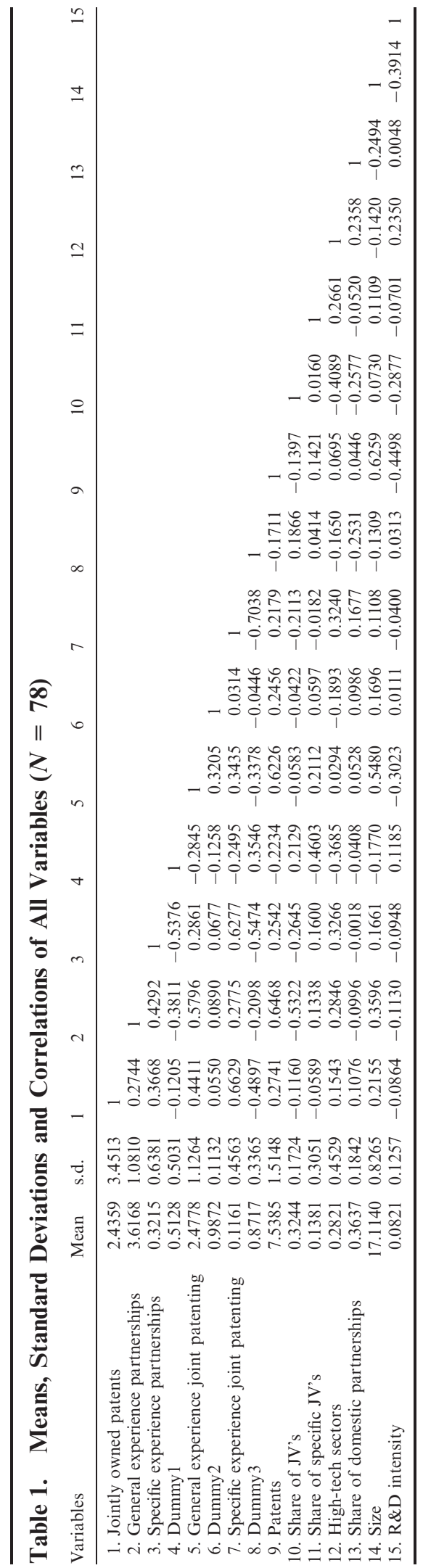

story. The number of jointly owned patents depends positively on the experience with joint patenting and not on the experience with $R \& D$ alliances.

As far as the control variables are concerned, our findings are quite straightforward: none of the control variables appear to play a role of any significance in the analysis. We also considered a number of possible interaction effects of various variables (not reported here) but none of the interaction effects were significant.

\section{DISCUSSION}

Our results clearly indicate that, somewhat surprisingly, the degree of joint patenting of companies is not directly related to their experience with formal R\&D partnering, not even for a group of companies that is heavily involved in both joint patenting and formal $\mathrm{R} \& \mathrm{D}$ collaboration through alliances. If one accepts that joint patenting is a possible indicator for the success of inter-firm cooperation, then this finding appears to tie into some contributions to the alliance literature that are skeptical about the positive effect of alliance experience on alliance outcome (Inkpen, 1995; Shortell and Zajac, 1988; Simonin, 1997). Specifically, neither the general or the specific experience of companies with establishing a variety of different partnerships is a sufficient condition for success. Our findings particularly suggest that increasing numbers of inter-firm $\mathrm{R} \& \mathrm{D}$ alliances do not imply that this experience will be translated into increasing joint patenting with partners. It should be stressed that our results do not indicate that formal R\&D partnering does not generate any results or that companies engaged in $R \& D$ alliances are unable to learn from their alliances. After all, it is still possible that partners do individually learn from their experience through a multitude of alliances. Through these alliances companies can appropriate knowledge that might be translated into separate patents, new technologies, new products or new production processes and managerial skills. However, the results suggest caution in suggesting that $R \& D$ alliances are merely successful or not successful.

The more positive results found for the effect of previous experience with joint patenting indicates the importance that should be attached to the role 


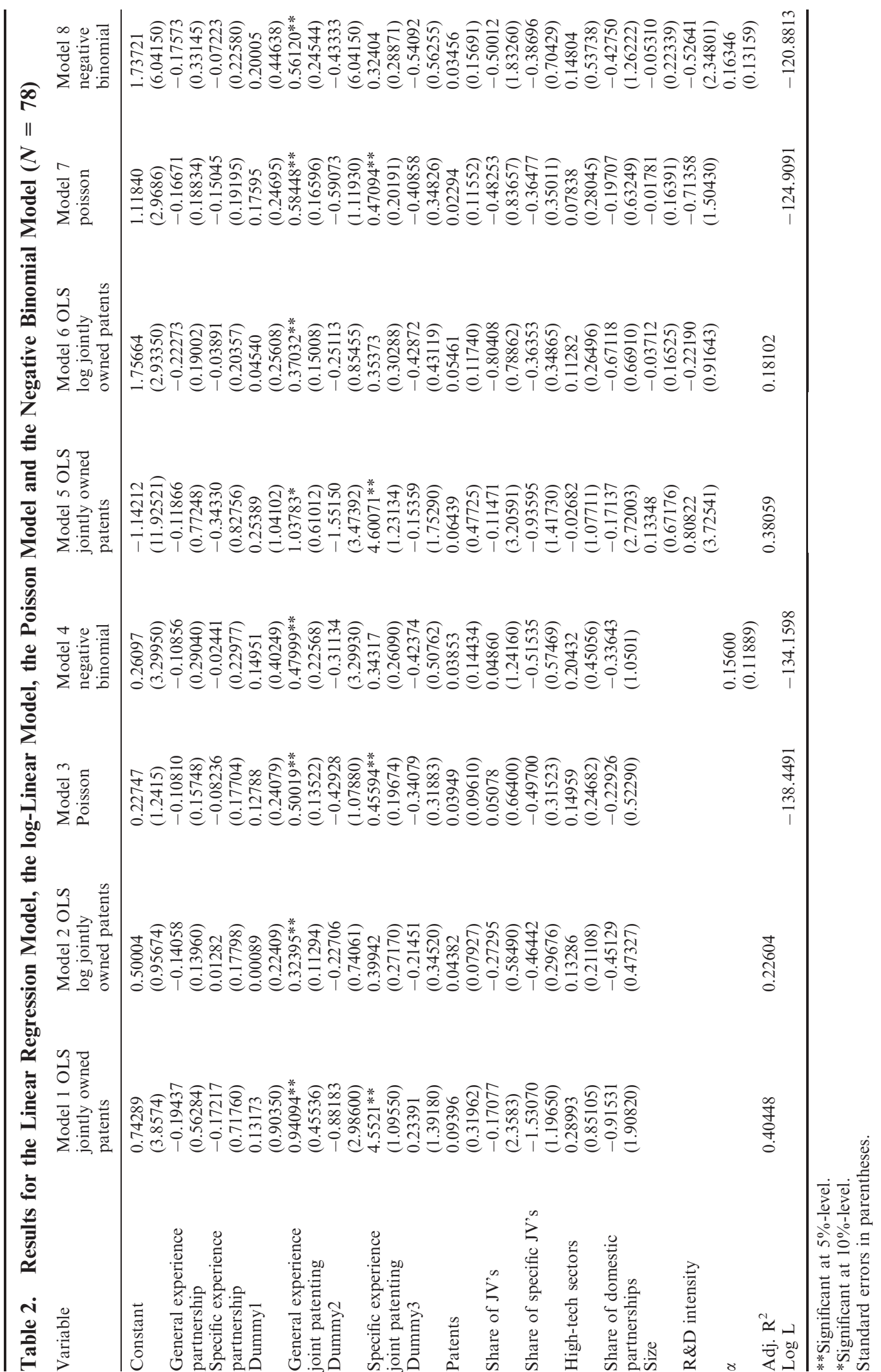

Copyright (C) 2003 John Wiley \& Sons, Ltd.

Manage. Decis. Econ. 24: 71-84 (2003) 
Table 3. Tests for Overdispersion in Poisson Model

\begin{tabular}{|c|c|c|c|}
\hline & $\hat{\alpha}$ & Standard error & $t$-ratio \\
\hline \multicolumn{4}{|l|}{ Model 3} \\
\hline$g\left(\mu_{i}\right)=\mu_{i}$ & 0.22470 & 0.32224 & 0.697 \\
\hline$g\left(\mu_{i}\right)=\mu_{i}^{2}$ & 0.18420 & 0.08963 & 2.055 \\
\hline \multicolumn{4}{|l|}{ Model 7} \\
\hline$g\left(\mu_{i}\right)=\mu_{i}$ & 0.24121 & 0.30678 & 0.786 \\
\hline$g\left(\mu_{i}\right)=\mu_{i}^{2}$ & 0.16342 & 0.07945 & 2.057 \\
\hline
\end{tabular}

of experience with joint patenting as such. The history of companies in joint patenting with a variety of partners indicates that firms may strategically select the joint patenting option and that they may have mastered the necessary knowledge relevant to arrange joint patent applications. In particular the result for the effect of general experience with joint patenting seems to imply that companies are able to learn from their previous experience of how to apply for joint patents with a variety of partners.

A somewhat speculative explanation for the positive role played by joint patenting experience points at the possible effect of informal networks of R\&D personnel from different companies. The role of informal networks is stressed in Bouty (2000) and von Hippel (1988) who argue that researchers are embedded in informal networks that cut across organizational boundaries and that they routinely share information with fellow researchers that they trust. In Thompson's terms (Thompson, 1967) they are members of a 'complex configuration' of informal networks that frequently have formal consequences. Bouty's (2000) study also suggests a tension between the desire to protect the firm and its technological capabilities and the need to collaborate to solve problems. Her work shows that the relationships between researchers is built over time and only via successful and trustful exchanges will researchers actively collaborate. The tension between protection of technological capabilities on the one hand and the practical need to collaborate on the other may be partially resolved by the development of joint benefits to the researchers and their firms as represented by a joint patent. In that case the propensity of companies to enter into joint patent agreements could be the result of informal networks at the level of $R \& D$ departments in a history of collaboration with a variety of companies where formal $R \& D$ partnerships do not play an active role.

Returning to joint patenting experience as such, it is important to note that our results are quite unambiguous when it comes to understanding the relation between the general experience with joint patenting. However, our findings regarding the specific experience of joint patenting companies are not that clear. Based on our current research it appears that the specific experience with joint patenting does not necessarily have the same effect on the joint ownership of patents as the general experience of companies with joint patenting. These results could be statistical artifacts caused by certain sensitivities in some of the statistical models due to small numbers. Although, given the exploratory nature of this study and the newness of these subjects, future research is required for all topics in this contribution, the role of specific experience within pairs of joint patenting companies seems particularly important for subsequent study.

\section{CONCLUSIONS}

As so many other exploratory studies, our research does not generate the results that one would expect based on related research, extension of current research, and simple intuition. Formal R\&D partnerships, such as joint ventures and R\&D pacts, may generate several results for the participating companies but the sharing of intellectual property rights through joint patenting does not seem to be among the benefits. This does indicate that our understanding of both inter-firm collaboration and the R\&D and innovation processes within companies is in need of substantial improvement. Apparently there are no simple oneon-one relationships, where one phenomenon (e.g. increasing joint R\&D) simply leads to another (e.g. increasing joint R\&D output), as one might expect from much of the current alliance and innovation literature.

However, our research does indicate one important finding. Again, it appears that previous experience of companies does guide their behaviour. Simplistic as this might seem, the bottomline might be that companies that once have built up some experience in joint patenting with other companies, through a variety of joint actions 
outside the realm of formal partnering, continue to do so. In other words, as already found for so many other aspects of company behaviour, firms appear to follow certain routines based on previous experiences and these routines to a large extent explain the variance in a population of companies. Once companies have learned how to share property rights with other companies, they continue to jointly patent with other companies.

\section{Acknowledgements}

Earlier versions of this paper were presented at the Academy of International Business Annual Meeting in Phoenix, November 2000, the Academy of Management Meeting in Washington DC, August 2001 and the Strategic Management Society in San Francisco, October 2001. We gratefully acknowledge the helpful suggestions to improve the paper made by participants at these conferences and the reviewers of this journal.

\section{REFERENCES}

Anand BN, Khanna T. 2000. Do firms learn to create value? The case of alliances. Strategic Management Journal 21 (Special issue): 295-316.

Balakrishnan S, Koza MP. 1993. Information asymmetry, adverse selection and joint ventures - Theory and evidence. Journal of Economic Behavior and Organization 20: 99-117.

Barkema HG, Shenkar O, Vermeulen F, Bell JHJ. 1997. Working abroad, working with others: how firms learn to operate international joint ventures. Academy of Management Journal 40: 426-442.

Berg SV, Duncan J, Friedman P. 1982. Joint Venture Strategies and Corporate Innovation. Gunn \& Hain: Cambridge, Oelgeschlager.

Bound J, Cummins C, Griliches Z, Hall BH, Jaffe A. 1984. Who does R\&D and who patents? In $R \& D$, Patents, and Productivity, Griliches Z (ed.). University of Chicago Press: Chicago; 21-54.

Bouty I. 2000. Interpersonal and interaction influences on informal resource exchanges between R\&D researchers across organizational boundaries. Academy of Management Journal 43: 50-65.

Buckley PJ, Casson M. 1988. A theory of cooperation in international business. In Cooperative Strategies in International Business, Contractor F, Lorange P (eds). Lexington Books: Lexington, MA; 31-54.

Cameron AC, Trivedi PK. 1986. Econometric models based on count data: comparisons and applications of some estimators and tests. Journal of Applied Econometrics 1: 29-53.

Cameron AC, Trivedi PK. 1990. Regression-based tests for overdispersion in the Poisson model. Journal of Econometrics 46: 347-364.

Cohen WM, Levin RC. 1989. Empirical studies of innovation and market structure. In 1989, Handbook of Industrial Organization, Vol. 2, Schmalensee R, Willig R (eds), Elsevier: Amsterdam; 1059-1107.
Contractor F, Lorange P (eds). 1988. Cooperative Strategies in International Business. Lexington Books: Lexington (MA).

Duysters G, Hagedoorn J. 1995. Strategic groups and inter-firm networks in international hightech industries. Journal of Management Studies 32: 361-381.

Dyer JH, Singh H. 1998. The relational view: cooperative strategy and sources of interorganizational competitive advantage. Academy of Management Review 23: 660-679.

Geringer JM. 1991. Strategic determinants of partner selection criteria in international joint ventures. Journal of International Business Studies 22: 41-62.

Ghemawat P, Porter ME, Rawlinson RA. 1986. Patterns of international coalition activity. In Competition in Global Industries, Porter ME (ed.). Harvard Business School Press: Boston (MA); 345-365.

Glaister KW, Buckley PJ. 1999. Performance relationships in UK international alliances. Management International Review 39: 123-147.

Gourieroux C, Monfort A, Trognon A. 1984a. Pseudo maximum likelihood methods: theory. Econometrica 52: $681-700$.

Gourieroux C, Monfort A, Trognon A. 1984b. Pseudo maximum likelihood methods: applications to Poisson models. Econometrica 52: 701-720.

Griliches Z. 1998. R\&D and Productivity-The Economic Evidence. The University of Chicago Press: Chicago.

Gulati R. 1995a. Social structure and alliance formation patterns: a longitudinal analysis. Administrative Science Quarterly 40: 619-652.

Gulati R. 1995b. Does familiarity breed trust? The implications of repeated ties for contractual choice in alliances. Academy of Management Journal 38: 85-112.

Hagedoorn J. 1993. Understanding the rationale of strategic technology partnering: inter-organizational modes of cooperation and sectoral differences. Strategic Management Journal 14: 371-385.

Hagedoorn J. 1995. A note on international market leaders and networks of strategic technology partnering. Strategic Management Journal 16: 241-250.

Hagedoorn J, Narula R. 1996. Choosing organizational modes of strategic technology partnering: international and sectoral differences. Journal of International Business Studies 27: 265-284.

Hagedoorn J, Schakenraad J. 1994. The effect of strategic technology alliances on company performance. Strategic Management Journal 15: 291-311.

Hausman J, Hall BH, Griliches Z. 1984. Econometric models for count data with an application to the patents-R\&D relationship. Econometrica 52: 909-938.

Heide JB, Miner AS. 1992. The shadow of the future: effects of anticipated interaction and frequency of contacts on buyer-seller cooperation. Academy of Management Journal 35: 265-291.

Hicks D, Narin F. 2000. Strategic research alliances and 360 degree bibliometric indicators. Paper presented at NSF workshop on Strategic research partnerships, Washington, DC. 
Inkpen A. 1995. Organizational learning and international joint ventures. Journal of International Management 1: 165-198.

Kale P, Singh H. 1999. Building alliance capabilities: a knowledge-based approach. Academy of Management Best Paper Proceedings, Chicago, Il.

Kamien MI, Schwartz NL. 1982. Market Structure and Innovation. Cambridge University Press: Cambridge.

Kogut B. 1989. The stability of joint ventures; reciprocity and competitive rivalry. Journal of Industrial Economics 38: 183-193.

Levinthal DA, Fichman M. 1988. Dynamics of interorganizational attachments: auditor-client relationships. Administrative Science Quarterly 33: 345-369.

Mansfield E. 1986. Patents and innovation: an empirical study. Management Science 32: 173-181.

Mowery DC (ed.). 1988. International Collaborative Ventures in US Manufacturing. Ballinger: Cambridge.

Mueller DC. 1986. The Modern Corporation-Profits, Growth and Performance. Wheatsheaf Books: Brighton.

Mytelka LK (ed.). 1991. Strategic Partnerships and the World Economy. Pinter: London.

Nooteboom B, Berger H, Noorderhaven NG. 1997. Effects of trust and governance on relational risk. Academy of Management Journal 40: 308-338.

OECD. 1992. Technology and the Economy. OECD: Paris.

Osborn RN, Baughn C. 1990. Forms of inter-organizational governance for multinational alliances. Academy of Management Journal 33: 503-519.

Osborn RN, Hagedoorn J. 1997. The institutionalization and evolutionary dynamics of interorganizational alliances and networks. Academy of Management Journal 40: 216-278.

Osborn RN, Hagedoorn J, Denekamp JG, Duysters G, Baughn CC. 1998. Embedded patterns of international alliance formation: an institutional perspective. Organization Studies 19: 617-638.

Oster SM. 1992. Modern Competitive Analysis. Oxford University Press: New York.

Park SH, Ungson GR. 1997. The effect of national culture, organizational complementarity and economic motivation on joint venture dissolution. Academy of Management Journal 40: 279-307.

Patel P, Pavitt K. 1991. Large firms in the production of the world's technology: an important case of nonglobalization. Journal of International Business Studies 22: $1-21$.

Powell WW, Koput KW, Smith-Doerr L. 1997. Interorganizational collaboration and the locus of innovation: networks of learning in biotechnology. Administrative Science Quarterly 41: 116-145.

Ring PS, van de Ven A. 1992. Structuring cooperative relationships between organizations. Strategic Management Journal 13: 483-498.

Saxton T. 1997. The effects of partner and relationship characteristics on alliance outcomes. Academy of Management Journal 40: 443-461.

Scherer FM. 1965. Firm size, market structure, opportunity, and the output of patented innovations. American Economic Review 15: 1097-1123.

Scherer FM. 1984. Innovation and growth: Schumpeterian Perspectives. MIT Press: Cambridge.

Shortell SM, Zajac EJ. 1988. Internal joint JVs: development processes and performance outcomes. Strategic Management Journal 9: 527-542.

Simonin BL. 1997. The importance of collaborative know-how: an empirical test of the learning organization. Academy of Management Journal 40: 1150-1174.

Thompson JD. 1967. Organization in Action. McGrawHill: New York.

Van de Ven AH, Polley DE, Garud R, Venkataraman S. 1999. The Innovation Journey. Oxford University Press: New York.

Von Hippel E. 1988. The Sources of Innovation. Oxford University Press: New York.

Williamson OE. 1996. The Mechanisms of Governance. Oxford University Press: Oxford.

Zaheer A, McEvily B, Perrone V. 1998. Does trust matter? Exploring the effects of interorganizational and interpersonal trust on performance. Organization Science 9: 141-159. 